A public servant since 1909, the whole of Robinson's long career was devoted to the cause of British forestry. The Forestry Commission, of which he was successively technical commissioner and chairman, owed its existence and policy very largely to his initiative and organizing ability.

Made a peer in 1947 in recognition of his outstanding services, he was the first forester to receive that honour. Characteristically, he took his title in part from the Border Forest of Kielder. The largest of the new forest blocks of his creating, it was also the one of which he was the most proud, partly perhaps because it exemplified the wisdom of his policy of proceeding step by step from the known to the unknown. It was not until the success of the pioneer afforestation at Smales in the Kielder area was reasonably assured that he agreed to the acquisition of the further large blocks which now comprise Kielder and the adjoining forests in the Border country.

Robinson's extensive tours of the forests in Great Britain and throughout the Commonwealth, as well as in many parts of Europe, reinforced by a remarkably retentive memory, gave him a uniquely wide experience of all branches of forestry. It was this wealth of experience which made him such a stimulating guide in the forest.

Robinson's approach to sylvicultural problems was essentially scientific, and although administrative work took up a large part of his time, his own contributions to our forestry knowledge were of no mean order. We owe to his fertile mind the highly original basis of the construction of our British yield tables which were built up from the measurements of 1,000 sample plots recorded in woodlands in the process of being felled during the First World War. Had it not been, too, for his foresight, all record of the rate of growth of these woods would have been irretrievably lost. Moreover, he was probably the first forester in any country to realize the importance of statistical lay-outs and analysis in field experimentation; in the early 1920's, he enlisted the aid of R. A. Fisher, then at Rothamsted, in order to ensure that the techniques being developed there for agricultural experiments were applied also to appropriate problems in forestry.

Lord Robinson's fine physique and handsome presence made him a conspicuous figure in any gathering. Inclined to be austere in the office, his reserve melted almost magically as soon as he got among his trees, when he was extremely good company. It was not until about two years ago, when an accident on one of his inspections of the Border country led to a serious illness, that he was obliged to curtail his outdoor activities to some extent; though even then he continued to cover an astonishing amount of ground, using a 'land rover' to get about over the forest tracks.

His many-sided gifts showed perhaps to the greatest advantage when he was presiding over a large meeting. Those who attended the Empire Forestry Conference held in South Africa in 1935 will long remember the tact and imperturbable good humour with which he conducted its affairs. It was while attending, as head of the British delegation, the Sixth Commonwealth Forestry Conference in Canada, that a sudden attack of pneumonia proved fatal. So at the height of his fame and almost at the end of his long and honourable career in the public service, a great man has departed; the nation is the poorer for his loss.

\section{Sir Frederic Kenyon, G.B.E., K.C.B.}

Str Frederic Kenyon, who died on August 23, gave forty-one of his eighty-nine years to the service of the British Museum. For the last twenty-one of them he was director and principal librarian. Born in 1863, the seventh of the fifteen children of John Robert Kenyon, Q.C., he laid the foundations of his classical learning as a scholar of Winchester and of New College, Oxford. First-classes in Moderations and in Literoe Humaniores led to a fellowship at Magdalen in 1888, and a year later he won the Chancellor's English Essay prize. In 1889 he entered the Department of Manuscripts of the British Museum, where he devoted himself to the cataloguing of the extensive and increasing collection of papyri. It was virtually an unworked field and a particularly attractive one for a brilliant young scholar. He made his name two years later by the discovery, publication, and translation of Aristotle's lost treatise on the Athenian Constitution. The text of this was edited for the Berlin Academy in 1904 and for the Clarendon Press in 1920. Other discoveries among the literary papyri were the Mimes of Herodas, an unknown speech of Hyperides, and twenty odes of Bacchylides, the latter from a roll acquired by the Museum in 1896. In 1899 appeared his well-known "Palæography of Greek Papyri". Other fruits of his scholarship were the "Catalogue of Greek Papyri in the British Museum" (vol. 1, 1893 ; vol. 2, 1898; vol. 3, 1907) and "Facsimiles of Biblical Manuscripts in the British Museum", published in 1900 . In addition to these official labours, he published in 1895 "Our Bible and the Ancient Manuscripts", a classic in this field and many times reprinted.

In 1909 he was chosen to be director of the British Museum at an unprecedentedly early age and in preference to not a few colleagues of senior rank and of great eminence in their different fields. It was a difficult situation calling for exceptional tact and wisdom. These qualities Kenyon possessed to the full, and with them urbanity, fairness, and administrative ability of the highest order. Never was the Museum more wisely and fairly governed; never had its prestige been raised to a higher level. Classical studies had sharpened his critical faculties, enabling him to lay bare with penetrating clarity the essentials of the most difficult problem. His capacity for business, coupled with firmness and courtesy, made him a model chairman, and he was at various periods president of the British Academy, of the Hellenic Society, of the Society of Antiquaries, and warden of Winchester College.* In 1918 he was selected as adviser to the Imperial War Graves Commission.

After his retirement in 1930, Kenyon gave himself largely to biblical studies, an early love, and to textual criticism in particular. He edited a series of biblical papyri which Mr. Chester Beatty had brought from Egypt, publishing the fruits of his labours in "Recent Developments in the Textual Criticism of the Greek Bible". To this work, produced in 1933, he added in 1948 "The Bible and Modern Scholarship", small in size, but weighty in content. A work of more popular appeal but not less scholarly was his "Books and Readers in Ancient Greece and Rome", which had appeared in 1932.

He was an honorary graduate of many universities. Many honours and decorations had fallen to him; but it is probable that he prized none more highly than the T.D. which marked his long connexion with the Territorial Army and with the Inns of Court Regiment 
in particular. Beginning the First World War as a company commander, he ended it as a lieutenantcolonel. Had he not chosen the path of scholarship, Kenyon might have been a soldier of distinction. He touched nothing which he did not adorn.

He married in 1891 Amy, daughter of Rowland Hunt. She died in 1938. Of his two daughters the elder is a well-known archæologist.

\section{F. G. Rendali}

\section{Dr. William McRae, C.I.E.}

WruLIaM McRaw was born in scotland in 1878 and graduated in the University of Edinburgh, from which he later received the degree of D.Sc. He arrived in India on March 28, 1908, and joined the Agricultural Service as a mycologist at the Imperial Institute of Agricultural Research, Pusa, now the Indian Agricultural Research Institute, New Delhi. Dr. McRae's services were placed at the disposal of the Government of Madras with effect from January 1, 1910, for employment in the local Agricultural Department, where he served for nine years as Government mycologist and as the principal of the Agricultural College. During the period of his tenure in Madras he developed both mycological research and teaching. He successfully conducted campaigns against the serious disease of palms which is responsible for bud-rot. Earlier he also investigated the blister blight of tea which was responsible for heavy losses in tea plantations in Darjeeling, and published an extremely valuable bulletin on the subject, in which he described the control measures of this serious disease.

In 1920 Dr. McRae returned to Pusa as head of the Mycological Section of the Imperial Institute for Agricultural Research, a post which he held until the end of his service, except for intervals when he acted as agricultural adviser to the Government of India or as agricultural expert to the Indian Council of Agricultural Research. $\mathrm{He}$ was responsible for valuable investigations on the wilt disease of pigeonpea, the mosaic disease of sugar-cane and also foot-rot of betel vine. He held the posts of joint director and that of director of the Imperial Institute of Agricultural Research, Pusa, in addition to his own duties, for short periods.

Dr. Mchae made valuable contributions to the investigation of plant diseases and published more than twenty-one scientific papers. In recognition of his work he was appointed C.I.E. in 1934. He was placed on the retired list after more than twentyfive years service on June 23, 1934. He was one of the most energetic men in the Indian Agricultural Service, and besides being an able scientist he also had the reputation of a good administrator and a great disciplinarian, who spared no pains in the development of mycological research and kept up the standards so well established by Dr. E. J. (later Sir Edwin) Butler, whom he succeeded. In Dr. McRae's death on July 8, India has lost not only an outstanding scientist, but also a friend who will be held in esteem for a long time to come.

R. S. VASUdeva

The Right Hon. Lord Macmillan, G.C.V.O.

Mr. W. D. STuRor, secretary to the Royal Commission for the Exhibition of 1851, writes: "Lord Macmillan, who died on September 5, was chairman of the Board of Management of the Royal Commission for the Exhibition of 1851. He took a close personal interest in the Commissioners' scheme of science research scholarships, and those who were present at the 1851 Scholars' Centenary Dinner in 1951 will surely remember him with affectionate respect. His great humanity enabled him to see scientific achievement in a true perspective, and he was not afraid to remind a gathering of distinguished scientists that they were first and foremost human beings. He was intensely proud of the scientific record of the Commissioners' research scholars, and maintained his active interest in the work of the Royal Commission until the day of his death. Scientists may well join with those in many other walks of life in mourning the loss of a great friend".

WE regret to announce the following deaths:

Prof. C. B. Fawcett, emeritus professor of geography in the University of London (University College), on September 21 , aged sixty-nine.

Mr. E. H. Godfrey, formerly chief of the Agricultural Branch, Dominion Bureau of Statistics, Canada, on September 22, aged ninety.

Prof. C. H. Lees, F.R.S., emeritus professor of physics in the University of London, formerly viceprincipal of Queen Mary College, on September 25, aged eighty-eight.

\section{NEWS and VIEWS}

\section{Emil Fischer (1852-1919)}

Emrr FIscher, who in his life-time exerted a profound influence on chemistry and chemists of his generation and whose discoveries in biochemistry are still yielding rich harvests, was born a century ago, on October 9, 1852, at Euskirchen in Rhenish Prussia. The son of a prosperous merchant, he was apprenticed for two years to his brother-in-law, a timber-merchant, on leaving school in 1869. His interest in experimental science led to his becoming a pupil of Friedrich August Kekulé at Bonn. After working as assistant to Adolf von Baeyer at Strasbourg and Munich, he held the chairs of chemistry at Erlangen and Würzburg, and in 1892 succeeded August Wilhelm von Hofmann as professor of chemistry at Berlin. As early as 1875 he discovered phenylhydrazine, "the path-finder of carbohydrate chemistry", and described its reaction with the sugars to form osazones. $\mathrm{H}_{\mathrm{e}}$ synthesized and formulated caffeine, xanthine, theobromine, glucose, fructose and veronal-the first of the barbiturates; developed a 'family tree' of gout, based on the purine nucleus; devised quantitative methods for isolating amino-acids, with which he prepared polypeptides; and, with Emil Abderhalden, did fundamental research on the specific action of enzymes. Keenly interested in the requirements of the chemical industry, he was instrumental in founding the Kaiser-Wilhelm Institut für Chemie in 1912 and in the First World War organized Germany's chemical resources. A tremendous worker with a splendid memory, Fischer was idolized by his 